\title{
Stimulation of In Vivo Dopamine Transmission in the Bed Nucleus of Stria Terminalis by Reinforcing Drugs
}

\author{
Ezio Carboni, Alessandra Silvagni, Maria T. P. Rolando, and Gaetano Di Chiara \\ Department of Toxicology and Consiglio Nazionale delle Ricerche Center for Neuropharmacology, University of Cagliari, \\ 09126 Cagliari, Italy
}

Drugs of abuse preferentially increase dopamine transmission in the shell of the nucleus accumbens. This area is considered as a transition between the striatum and the extended amygdala a complex neural system that includes the central amygdala and the bed nucleus of stria terminalis, areas that, like the nucleus accumbens shell, are heavily innervated by mesolimbic dopamine neurons originating in the ventral tegmental area. Given the anatomical and neurochemical relationships and similarities with the nucleus accumbens shell it was of interest to investigate whether the dopamine transmission of the bed nucleus of stria terminalis shares with the accumbens shell the peculiar responsiveness to drugs of abuse. To this end we

Drugs and substances of abuse like nicotine, morphine, cocaine, and ethanol share the property of increasing extracellular dopamine (DA) in the nucleus accumbens (NAc) and in particular in its ventromedial shell subdivision (Imperato and Di Chiara, 1988; Pontieri et al., 1996; Tanda et al., 1997b). This property is currently assigned an important role in the addictive liability of drugs and in the process by which drug addiction is acquired and maintained. Anatomical and histochemical studies show that the NAc shell is homologous to a number of interconnected areas as the bed nucleus of stria terminalis (BNST) and the central amygdala that have been recently assigned to the so called extended amygdala (Heimer et al., 1993; de Olmos and Heimer, 1999). The areas and nuclei that participate into this complex share a role in the acquisition and expression of emotions and of appetitive behavior (e.g., feeding and sexual behavior) (Hernandez and Hoebel, 1988; Tetel et al., 1993; Pfaus et al., 1995). Thus, the NAc shell and the BNST receive a dense innervation from the basolateral amygdala and a dense DA projection from the ventral tegmentum and both project to the lateral hypothalamus and periaqueductal gray (de Olmos, 1972, 1990; de Olmos et al., 1985; Phelix et al., 1992). Strict similarities and connections also exist between BNST and central nucleus of amygdala in terms of cell morphology, transmitter content, and efferent connections (Alheid et al., 1995). The BNST is innervated by neurons containing peptides as cholecystokinin (Micevych et al., 1988; Andres et al., 1993) and corticotropin-releasing factor (CRF) (Cummings et al., 1983; Phelix et al., 1994). The BNST is thought to be involved in aversive behavior and in the somatic response to unconditioned aversive stimuli (Davis and Shi, 1999).

Recently it has been reported that intra BNST infusion of a DA $D_{1}$ receptor antagonist impairs cocaine intravenous selfadministration in rats (Epping-Jordan et al., 1998); moreover,

\footnotetext{
Received Dec. 6, 1999; revised Aug. 1, 2000; accepted Aug. 2, 2000.

This work has been supported by the Ministero dell'Universitá e della Ricerca Scientifica e Tecnologica 60 and $40 \%$.

Correspondence should be addressed to Dr. Ezio Carboni, Department of Toxicology, Viale Diaz 182, 09126 Cagliari, Italy. E-mail: ecarboni@unica.it.

Copyright (C) 2000 Society for Neuroscience $0270-6474 / 00 / 200001-05 \$ 15.00 / 0$
}

studied by microdialysis with concentric probes, the effect of drugs of abuse on extracellular dopamine in the bed nucleus of stria terminalis. We report that morphine, nicotine, cocaine, ethanol, and the selective dopamine uptake inhibitor GBR 12909 increase effectively and dose dependently extracellular dopamine in the bed nucleus of stria terminalis. These results indicate that the bed nucleus of stria terminalis shares with the nucleus accumbens shell a peculiar sensitivity to the dopamine stimulant actions of drugs of abuse.

Key words: dopamine; BNST; nicotine; morphine; ethanol; cocaine

intra-BNST infusion of a CRF-antagonist impairs stress-induced reinstatement of cocaine self-administration in rats (Erb and Stewart, 1999). In view of these observations and of the relationships between the shell of the NAc shell and the BNST we thought that this area could also be involved in the DA-dependent mechanism of action of drugs of abuse. We therefore studied by the microdialysis, the action of various drugs on the extracellular concentration of DA in the BNST.

\section{MATERIALS AND METHODS}

Animals. Male Sprague Dawley rats (Charles River, Calco, Italy) weighing 230-250 gm were housed under standard conditions of temperature and humidity under an artificial light (light from 8:00 A.M. to 8:00 P.M.).

Probe preparation. Concentric dialysis probes were prepared with a 7 mm piece of AN 69 (sodium methallyl sulfate copolymer) dialysis fiber (outer diameter, $310 \mu \mathrm{m}$; inner diameter, $220 \mu \mathrm{m}$; Hospal, Dasco, Italy), sealed at one end with a drop of epoxy glue. Two 5-cm-long pieces of fused silica (Composite Metal Services) tubing were introduced in the dialysis fiber taking care to have the inlet reaching the lower end and the outlet reaching the higher end of the dialyzing portion $(2.0 \mathrm{~mm})$ of the fiber. The inlet and the outlet were then sealed to the fiber and to a $20 \mathrm{~mm}$ piece of stainless steel (obtained from a 24 gauge needle) that were then inserted into a piece of $200 \mu \mathrm{l}$ micropipette tip 7-mm-long and glued to it. The fiber was covered with a thin layer of epoxy glue except for the dialyzing part. The probe was left to dry for $24 \mathrm{hr}$ (Di Chiara 1990).

Surgery and experiments. Rats were anesthetized with ketamine (Ketalar; Parke-Davis, Milan, Italy), placed in a stereotaxic apparatus. The skull was exposed, and a small hole was drilled on one side. The probe

This article is published in The Journal of Neuroscience, Rapid Communications Section, which publishes brief, peerreviewed papers online, not in print. Rapid Communications are posted online approximately one month earlier than they would appear if printed. They are listed in the Table of Contents of the next open issue of JNeurosci. Cite this article as: JNeurosci, 2000, 20:RC102 (1-5). The publication date is the date of posting online at www.jneurosci.org.

http://www.jneurosci.org/cgi/content/full/4614 

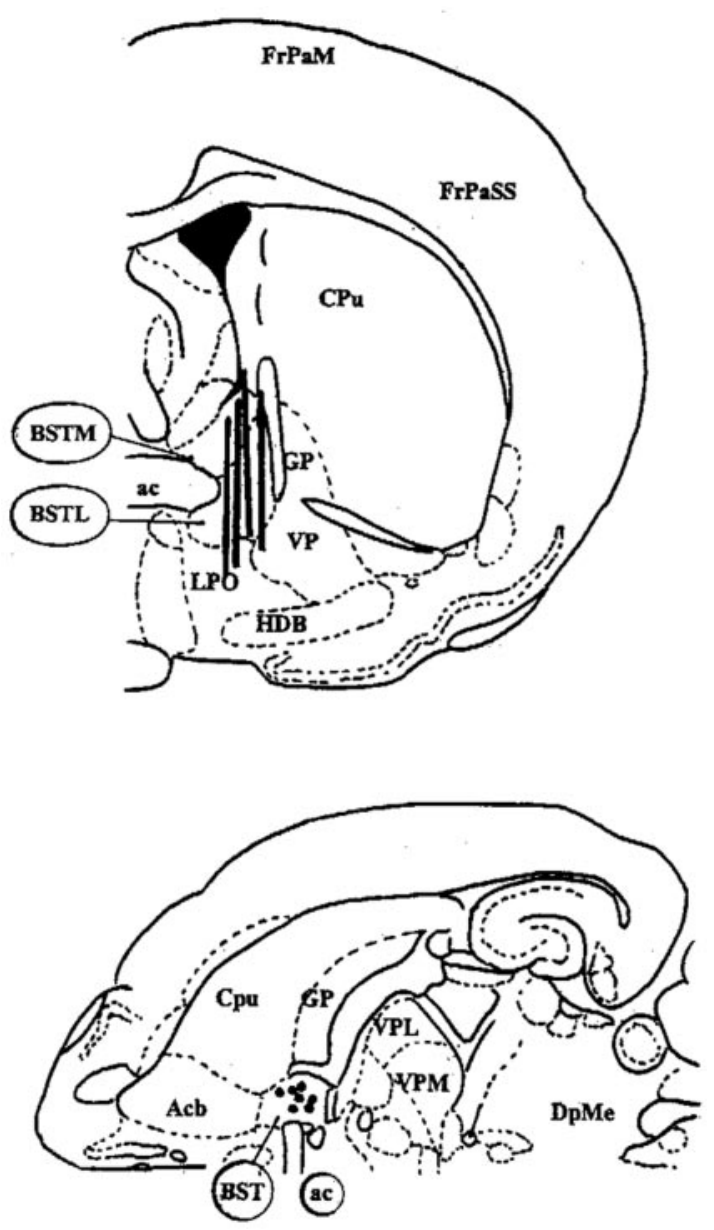

Figure 1. Schematic representation of a frontal section (top drawing) and horizontal section (bottom drawing) of rat brain at $\mathrm{A},-0.3 \mathrm{~mm}$ and $\mathrm{V}, 6.6$ from bregma, respectively, according to the atlas of Paxinos and Watson (1982). In the frontal section the position of the dialyzing part of the fiber is illustrated approximately as observed in one frontal section at the level of the central part of the BNST. $a c$, Anterior commissure; $A c b$, accumbens nucleus; BSTL, bed nucleus stria terminalis lateralis; $B S T M$, bed nucleus stria terminalis medialis; $C p u$, caudate putamen; $D p M e$, deep mesencephalic nucleus; $\mathrm{FrPaM}$, frontoparietal cortex, motor area; $\mathrm{FrPaSS}$, frontoparietal area, somatosensory area; $G P$, globus pallidus; $H D B$, nucleus horizontal limb diagonal band; $L P O$, lateral preoptic area; $V P$, ventral pallidum; $V P L$, ventroposterior thalamic nucleus lateralis; $V P M$, ventroposterior thalamic nucleus medialis.

was implanted vertically in the BNST [anterior (A), -0.5 ; lateral $(\mathrm{L}), 1.3$; vertical $(\mathrm{V}),-8.0$, from the dura], according to the atlas of Paxinos and Watson (1987), and then fixed on the skull with dental cement. Some rats were implanted $1 \mathrm{~mm}$ lateral or $1.2 \mathrm{~mm}$ anterior to the BNST site. Rats were housed in a transparent plastic (Plexiglas) hemisphere, closed with a top hemisphere, with food and water available ad libitum.

Experiments were performed on freely moving rats $24 \mathrm{hr}$ after probe implant. Ringer's solution ( $\left.147 \mathrm{~mm}, \mathrm{NaCl} ; 2.2 \mathrm{mM} \mathrm{CaCl}_{2} ; 4 \mathrm{mM} \mathrm{KCl}\right)$ was pumped through the dialysis probe at constant rate of $1 \mu \mathrm{l} / \mathrm{min}$. Samples were taken every $20 \mathrm{~min}$ and analyzed.

Figure 1 shows the position of the dialyzing part of the fiber in a schematic representation of a frontal section of the rat brain at the level of BNST (A, -0.3 mm) redrawn from Paxinos and Watson (1987). Probes implanted $1 \mathrm{~mm}$ lateral to the BNST had fibers located in the globus pallidus, whereas probes implanted $1.2 \mathrm{~mm}$ anterior to the BNST had fibers located in the caudal NAc shell. All animal experimentation has been conducted in accordance with the guidelines for care and use of experimental animals of the European Economic Community (86/809; DL 27.01.92 number 116).

Analytical procedure. Dialysate samples $(20 \mu \mathrm{l})$ were injected without any purification into an HPLC apparatus equipped with reverse-phase column (LC-18 DB; Supelco) and a coulometric detector (ESA Coulochem II, Bedford, MA) to quantitate DA. The first electrode was set at $+130 \mathrm{mV}$ and the second electrode at $-125 \mathrm{mV}$ ). The composition of the

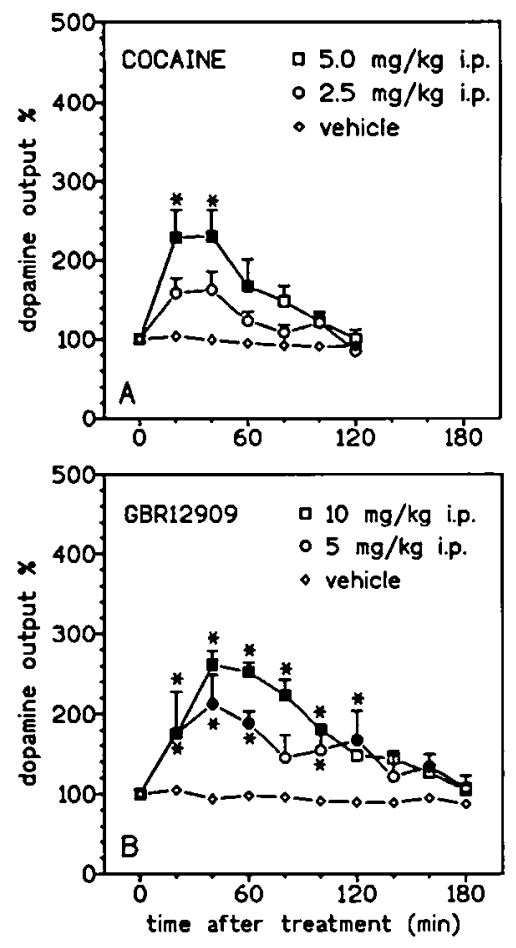

Figure 2. Effect of cocaine at 2.5 and $5 \mathrm{mg} / \mathrm{kg}$ (as $\mathrm{HCl}$ salt), intraperitoneally $(A)$ and of GBR 12909 at 5 and $10 \mathrm{mg} / \mathrm{kg}$, intraperitoneally $(B)$ on dopamine concentration in dialysate obtained by in vivo microdialysis from the BNST. Each point is the mean ( \pm SEM) of at least four determinations. Filled symbols: $p<0.05$ from basal values concentration; ${ }^{*} p<0.05$ from the correspondent time point of vehicle group.

mobile phase was: $50 \mathrm{~mm} \mathrm{Na} \mathrm{H} \mathrm{PO}_{4} / 5 \mathrm{mM} \mathrm{Na}_{2} \mathrm{HPO}_{4}, 0.1 \mathrm{~mm} \mathrm{Na} \mathrm{N}_{2}$ EDTA, $0.5 \mathrm{~mm}$ octyl sodium sulfate, and $15 \%$ (v/v) methanol, $\mathrm{pH}$ 5.5. The mobil phase was pumped with an LKB-Wallac (Gaithersburg, MD) 2150 pump at a flow rate of $1.0 \mathrm{ml} / \mathrm{min}$. The sensitivity of the assay allowed to detect 5 fmol of DA.

Histology. At the end of the experiment, rats were anesthetized and transcardially perfused with $100 \mathrm{ml}$ of saline $(0.9 \% \mathrm{NaCl})$ and $100 \mathrm{ml}$ of formaldehyde $(10 \%)$. The probes were removed, and brains were cut on a Vibratome in serial coronal slices oriented according the atlas of Paxinos and Watson (1987). The lateral margin of the anterior commissure and the internal capsule were taken as reference structures to identify the BNST. Results from rats implanted outside the BNST were discarded.

Drugs. Nicotine tartrate, morphine $\mathrm{HCl}$, and cocaine $\mathrm{HCl}$ were obtained from Sigma (Milano, Italy), ethanol by Carlo Erba, and GBR 12909 was a gift from by Novo A/S (Bagsveerd, Denmark).

Statistics. Statistical analysis was performed by Statistica (Statsoft). Two-way ANOVA for repeated measures was applied to the data expressed as percentage of basal DA concentration obtained from the serial assays of DA after each treatment. Results from treatments showing significant overall changes were subjected to post hoc Tukey test with significance for $p<0.05$. Basal values were the means of three consecutive samples differing $<10 \%$. Each implanted rat was challenged with a single dose of the test drug only once.

\section{RESULTS}

Basal values of DA in the BNST were $15.8 \pm 0.9 \mathrm{fmol} / 20 \mu \mathrm{l}$ sample (mean $\pm \mathrm{SEM} ; n=71$ ). As shown in Figure 1 probes were localized mostly in the lateral part of the BNST.

A significant increase of dialysate DA (expressed as percentage above basal values) was elicited by the following drugs of abuse: cocaine (Fig. $2 A)[2.5 \mathrm{mg} / \mathrm{kg}$, i.p. $(\max +62 \%)$ and $5.0 \mathrm{mg} / \mathrm{kg}$, i.p. $(\max +129 \%)]$, morphine (Fig. $3 A)[0.5 \mathrm{mg} / \mathrm{kg}$, s.c. $(\max +$ $76 \%)$ and $1.0 \mathrm{mg} / \mathrm{kg}$, s.c. $(\max +141 \%)]$; nicotine (Fig. $3 B)[0.1$ $\mathrm{mg} / \mathrm{kg}$, s.c. $(\max +85 \%)$ and $0.4 \mathrm{mg} / \mathrm{kg}$, s.c. $(\max +190 \%)]$; ethanol (Fig. $3 C$ ) $[0.25 \mathrm{gm} / \mathrm{kg}$, i.p. $(\max +58 \%)$ and $0.5 \mathrm{gm} / \mathrm{kg}$, i.p. $(\max +111 \%)$ ]. The specific DA reuptake inhibitor GBR 12909 (Fig. 2B) elicited an increase of DA dialysate $[5.0 \mathrm{mg} / \mathrm{kg}$, 

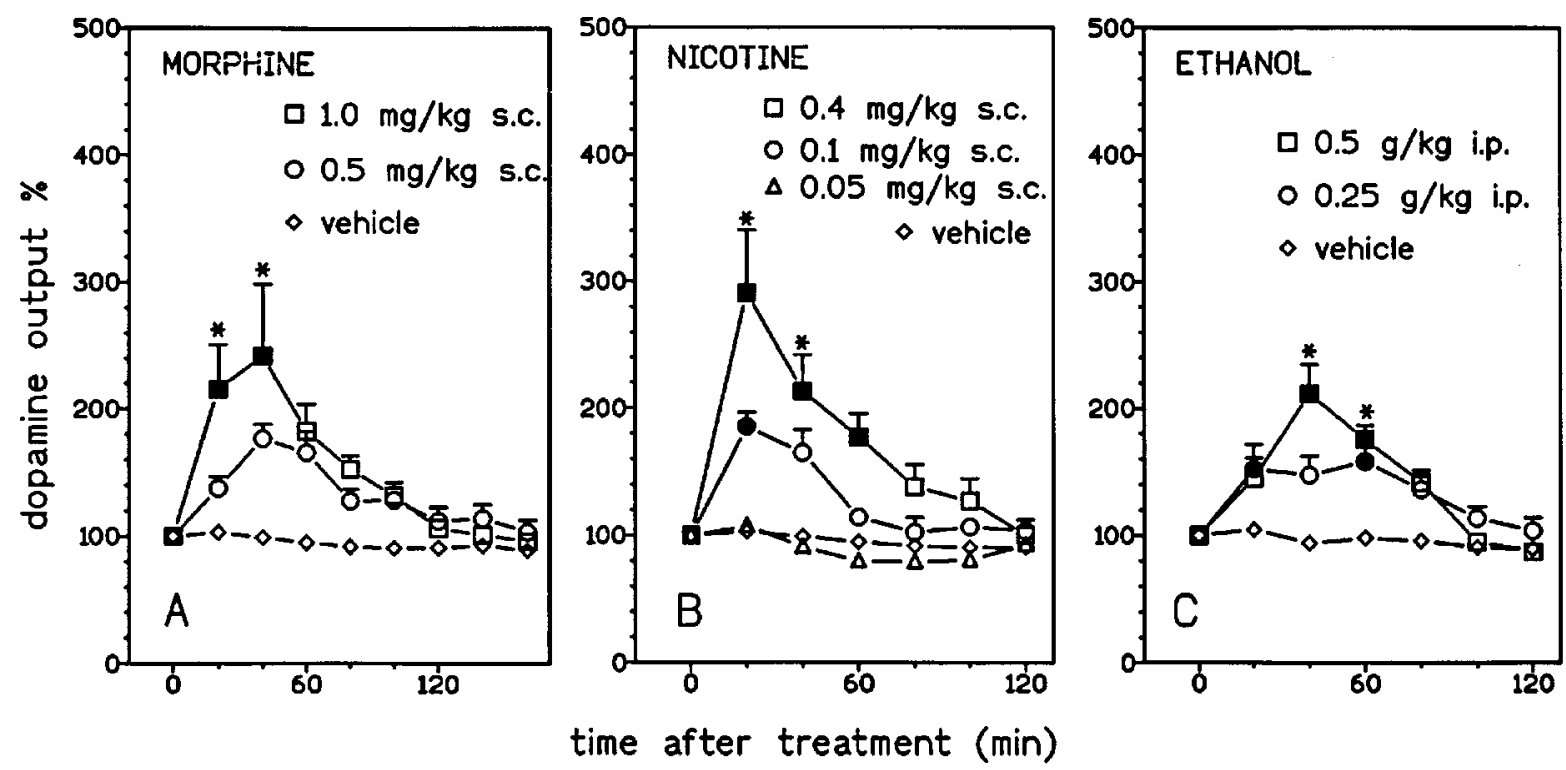

Figure 3. Effect of morphine $(A)$ at 0.5 and $1 \mathrm{mg} / \mathrm{kg}$ (as $\mathrm{HCl}$ salt) subcutaneously, nicotine $(B)$ at $0.05,0.1$, and $0.4 \mathrm{mg} / \mathrm{kg}$ (as free base) subcutaneously, and ethanol $(C)$ at 0.25 and $0.5 \mathrm{gm} / \mathrm{kg}$ (injected as $10 \% \mathrm{v} / \mathrm{v}$ solution) intraperitoneally on dopamine concentration in dialysate obtained by in vivo microdialysis from the BNST. Each point is the mean ( \pm SEM) of at least four determinations. Filled symbols: $p<0.05$ from basal values concentration; $* p<0.05$ from the correspondent time point of vehicle group.

i.p. $(\max +112 \%)$ and $10 \mathrm{mg} / \mathrm{kg}$, i.p. $(\max +161 \%)]$. Two-way ANOVA of the results obtained by the different doses of the above listed drugs showed a significant effect of dose and significant dose $\times$ time interaction for cocaine (main effect: $F_{(2,12)}=$ 4.11, $p<0.05$; interaction: $\left.F_{(12,72)}=4.19, p<0.001\right)$, nicotine (main effect: $F_{(3,17)}=14.19, p<0.001$; interaction: $F_{(18,102)}=$ 4.51, $p<0.001$ ), morphine (main effect: $F_{(2,16)}=5.9, p<0.05$; interaction: $\left.F_{(16,128)}=1.85, p<0.05\right)$, ethanol (main effect: $F_{(2,13)}$ $=11.17, p<0.005$; interaction: $\left.F_{(12,78)}=3.16, p<0.005\right)$ and GBR 12909 (main effect: $F_{(2,9)}=8.42, p<0.01$; interaction: $\left.F_{(18,81)}=7.13, p<0.001\right)$. When the microdialysis probe was implanted in the globus pallidus ( $1 \mathrm{~mm}$ lateral to the BNST) basal values of DA were $90.75 \pm 9.35 \mathrm{fmol} / 20 \mu \mathrm{l} \mathrm{sample} \mathrm{(mean} \pm \mathrm{SEM}$; $n=8$ ). Challenge with $0.4 \mathrm{mg} / \mathrm{kg}$ of nicotine produced a nonsignificant increase of dialysate DA by $18 \%$ above basal (main effect: $F_{(1,6)}=0.86, p=0.38$; interaction: $F_{(6,36)}=1.57, p=0.18$ (data not shown). When the microdialysis probe was implanted in the caudal NAc (1.2 mm rostral to the BNST site), basal values of DA were $75.63 \pm 11.40 \mathrm{fmol} / 20 \mu \mathrm{l}$ sample (mean $\pm \mathrm{SEM} ; n=8)$. Challenge with $0.4 \mathrm{mg} / \mathrm{kg}$ of nicotine maximally increased DA in dialysate by $78 \%$ above basal (main effect: $F_{(1,6)}=25.83, p<$ 0.002 ; interaction: $\left.F_{(6,36)}=11.51, p<0.0001\right)$ (data not shown).

\section{DISCUSSION}

This study shows that reinforcing drugs like nicotine, morphine, ethanol, and cocaine increase dialysate DA in the BNST. This effect is shared by the selective DA reuptake inhibitor GBR 12909, which is self-administered by rats (Roberts, 1993; Tella et al., 1996) and by monkeys (Villemagne et al., 1999).

\section{Topographic specificity of drug effect}

The BNST is surrounded by DA-rich areas both laterally (caudate putamen/globus pallidus) and cranially (NAc shell). In view of this, one could argue that the changes induced by the drugs do not arise from the BNST itself but are the result of DA diff usion from adjacent areas. This possibility however is unlikely for a number of reasons: first, the time course of drug-induced changes of dialysate DA in the BNST does not provide any indication (e.g., delayed and attenuated changes) of the above mechanism. To the contrary, drug-induced changes in BNST DA are sharper than in the NAc shell; second, as shown by the effect of nicotine at sites located cranially or laterally to the BNST, the changes in dialysate DA are specific to the implanted area being independent from basal dialysate DA. Thus, in spite of the similarity in the basal levels of DA, the laterally located globus pallidus does not respond to nicotine, whereas the cranially located NAc shell responds, although less than the BNST, to nicotine. Finally, the diffusion coefficient of DA in brain tissue is such that at a distance of $0.7 \mathrm{~mm}$ from the dialysis membrane the amount of DA recovered by the dialysis probe has been found to be negligible (Rice et al., 1985; Nicholson and Rice, 1986). In DA-rich areas, such as the NAc shell the presence of an efficient DA reuptake should further reduce the already limited diff usion of DA in brain tissue. This is further demonstrated by the fact that clear-cut differences in the effect of drugs of abuse can be obtained within the NAc itself between medial and lateral locations $1 \mathrm{~mm}$ apart (Pontieri et al., 1996; Tanda et al., 1997b). These observations and considerations exclude that the changes recorded in the BNST are the result of diffusion of DA from the adjacent NAc shell.

\section{Mechanism of drug effects}

The mechanism by which reinforcing drugs increased DA in the BNST is likely to be different depending on the drug class to which they belong.

\section{Cocaine and GBR 12909}

Cocaine-induced increase of dialysate DA in the BNST is most likely because of blockade of DA carrier. Consistent with this mechanism is the observation that the specific DA reuptake inhibitor GBR 12909 also increased DA in this area. We have previously reported (Carboni et al., 1990; Tanda et al., 1997a) that, in contrast with cocaine, GBR 12909 does not increase DA output in the prefrontal cortex (PfCx); on the contrary, the norepinephrine (NE) reuptake inhibitor desipramine (DMI) is highly effective in raising the dialysate DA in the PfCx but not in the NAc. These data suggest that in an area in which NE transmission is strongly represented DA could be taken up NE terminals. In the BNST NE terminals are located in the medial rather than in the lateral part (Moore, 1978; Phelix et al., 1992). Therefore in the lateral part of BNST, where probes were mostly 
located, the extent of DA uptake by NE terminals should be minimal. This explains the effectiveness of GBR 12909 and the failure of DMI (data not shown) in raising DA in the BNST. An increase of DA in the BNST might play a role in the reinforcing properties of cocaine. This view is supported by the observation that bilateral intracranial injections of the $\mathrm{D}_{1}$ receptor antagonist SCH 23390 into the lateral BNST partially attenuates the reinforcing effects of cocaine under a fixed-ratio schedule (EppingJordan et al., 1998). This observation is in turn consistent with the high level of DARP 32 in BNST (Shalling et al., 1990), a protein associated with neurons expressing $\mathrm{D}_{1}$ receptors.

\section{Morphine}

The present observation that morphine potently and dosedependently increased DA output in the BNST further supports the strict relationship between DA and the reinforcing properties of opioids (Johnson and North, 1992; Di Chiara, 1995). An involvement of BNST in the mechanism of action of opioids is suggested by the observation that naltrexone precipitated opiate withdrawal is associated with an increase in the early gene FOS in the ventral and dorsolateral region of BNST where DA innervation is more dense (Aston-Jones et al., 1999).

\section{Nicotine}

The systemic administration of nicotine effectively and dose dependently increased dialysate DA in the BNST. This effect is likely to be because of stimulation of DA neurons that from the VTA project to both the NAc shell and the BNST (Mereu et al., 1987; Pidoplicko et al., 1997) and through presynaptic nicotine receptors on DA terminals (Marshall et al., 1997; Wonnacott, 1997).

\section{Ethanol}

Ethanol increased in a dose-dependent manner DA output in the BNST. By analogy with the ethanol-induced increase of DA in the NAc (Imperato and Di Chiara, 1988) also the effect in the BNST is likely to be the result of stimulation of the firing of VTA neurons (Gessa et al., 1985). On the other hand a possible involvement of GABAergic transmission of the BNST has been suggested by Hyytia and Koob (1995) on the basis of the observation that injection of the competitive $\mathrm{GABA}_{\mathrm{A}}$ receptor antagonist SR 95531 into the BNST as well as into the NAc shell and in the central amygdala reduced ethanol responding in a twolever free choice operant task. Recently Davis and Shi (1999) showed that local injection of the glutamate antagonist NBQX into the BNST significantly decreased light-enhanced startle reflex, suggesting that BNST plays a role in anxiety. As ethanol is known to have antianxiety effects one might speculate that DA in the BNST may play a role in this effect; in fact, the BNST is rich of $\mathrm{D} 2$ receptors, which might be located in glutamate terminals where they could inhibit glutamate release by analogy with their action in the caudate putamen (Morari et al., 1998).

\section{Conclusions}

The results presented here indicate that cocaine, morphine, nicotine, and ethanol share the property of increasing DA transmission in the BNST. This effect may be related to an action at the level of neuronal circuits activated by natural reinforcers like food and sexual activity where DA might play an active role (Du et al., 1998; Meredith et al., 1998).

The present observation together with the results of local infusion studies (Epping-Jordan et al., 1998) suggest that DA transmission of the BNST plays a role in the mechanism of drug abuse and addiction. From a more general point of view, the observation that an area such as the BNST that has been included in the extended amygdala shares with the NAc shell, which is considered a transition area between the extended amygdala and the striatum, the sensitivity to drugs of abuse, is consistent with the notion of the existence of strict homologies between the shell of the NAc and the extended amygdala as far as concerns their role in emotional and motivational functions.

\section{REFERENCES}

Alheid G, De Olmos JS, Beltramino CA (1995) Amygdala and extended amygdala. In: The rat nervous system (Paxinos G, ed), pp 485-578. New York: Academic.

Andres ME, Forray MI Barria CG, Gysling K (1993) Studies of cholecystokinin in the rat bed nucleus of stria terminalis. Biochem Pharmacol 45:2283-2288.

Aston-Jones G, Delfs JM, Druhan J, Zhu Y (1999) The bed nucleus of stria terminalis: A target site for noradrenergic actions in opiate withdrawal. In: Advancing from the ventral striatum to the extended amygdala, Vol 877 (McGinty FJ, ed), pp 486-498. New York: Ann NY Acad Sci.

Carboni E, Tanda GL, Frau R, Di Chiara G (1990) Blockade of the noradreanaline carrier increases extracellular dopamine concentrations in the prefrontal cortex: evidence that dopamine is taken up in vivo by noradrenergic terminals. J Neurochem 55:1067-1070.

Cummings S, Elde R, Ells J, Lindall A (1983) Corticotropin releasing factor reactivity is widely distributed within the central nervous system of the rat: an immunohistochemical study. J Neurosci 3:1355-1368.

Davis M, Shi C (1999) The extended amygdala: are the central nucleus of the amygdala and the bed nucleus of the stria terminalis differentially involved in fear versus anxiety? In: Advancing from the ventral striatum to the extended amygdala, Vol 877 (McGinty FJ ed), pp 281-291. New York: Ann NY Acad Sci.

de Olmos JS (1972) The amygdaloid projection field in the rat as studied with the cupric silver method. In: The neurobiology of the amygdala (Eleftheriou BE, ed), pp 145-204. New York: Plenum.

de Olmos JS (1990) Amygdala. In: The human nervous system (Paxinos G, ed), pp 583-710. San Diego: Academic.

de Olmos JS, Heimer L (1999) The concepts of the ventral striatopallidal system and extended amygdala. In: Advancing from the ventral striatum to the extended amygdala, Vol 877 (McGinty FJ, ed), pp 1-32. New York: Ann NY Acad Sci.

de Olmos JS, Alheid GF, Beltramino CA (1985) Amygdala. In: The rat nervous system (Paxinos G, ed), pp 223-334. San Diego: Academic.

Di Chiara G (1990) "In vivo" brain dialysis of neurotransmitters. Trends Pharmacol Sci 11:116-121.

Di Chiara G (1995) The role of dopamine in drug abuse viewed from the perspective of its role in motivation. Drug Alcohol Depend 38:95-137.

Du J, Lorrain SD, Hull EM (1998) Castration decreases extracellular, but increases intracellular, dopamine in medial preoptic area of male rats. Brain Res 782:11-17.

Epping-Jordan MP, Markou A, Koob GF (1998) The dopamine D-1 receptor antagonist SCH 23390 injected into the dorsolateral bed nucleus of the stria terminalis decreased cocaine reinforcement in the rat. Brain Res 784:105-115.

Erb S, Stewart J (1999) A role for the bed nucleus of the stria terminalis, but not the amygdala, in the effects of corticotropin-releasing factor on stress-induced reinstatement of cocaine seeking. J Neurosci 19:RC35:1-6.

Gessa GL, Muntoni F, Collu M, Vargiu L, Mereu GP (1985) Low doses of ethanol activate dopaminergic neurons in the ventral tegmental area. Brain Res 348:201-203.

Heimer L, Alheid GF, Zahm DS (1993) Basal forebrain organization: an anatomical framework for motor aspects of drive and motivation. In: Limbic motor circuits and neuropsychiatry (Kalivas PW, Barnes CD, eds), pp 1-43. Boca Raton, FL: CRC.

Hernandez L, Hoebel BG (1988) Feeding and hypothalamic stimulation increases dopamine turnover in the accumbens. Physiol Behav 44:599-606.

Hyytia P, Koob GF (1995) GABA $_{\mathrm{A}}$ receptor antagonism in the extended amygdala decreases ethanol self-administration in rats. Eur J Pharmacol 283:151-159.

Imperato A, Di Chiara G (1988) Preferential stimulating of dopamine release in the nucleus accumbens of freely moving rats by ethanol. J Pharmacol Exp Ther 239:219-228.

Johnson SW, North RA (1992) Opioids excite dopamine neurons by hyperpolarization of local interneurons. J Neurosci 12:483-488.

Marshall DL, Redfern PH, Wonnacott S (1997) Presynaptic nicotinic modulation of dopamine release in the three ascending pathways studied by in vivo microdialysis: comparison of naive and chronic nicotinetreated rats. J Neurochem 68:1511-1519.

Meredith JM, Moffatt AC, Auger AP, Snyder GL, Grengard P, Blaustein JD (1998) Mating-related stimulation induced phosphorylation of dopamine- and cyclic AMP-regulated phosphoprotein-32 in progestin receptor-containing areas in the female rat brain. J Neurosci 18:10189-10195.

Mereu G, Yoon K, Boi V, Gessa GL, Naes L, Westfall TC (1987) Preferential stimulation of ventral tegmental area dopaminergic neurons by nicotine. Eur J Pharmacol 141:395-399. 
Micevych P, Akesson T, Elde R (1988) Distribution of cholecystokininimmunoreactive cell bodies in the male and female rat: II Bed nucleus of stria terminalis and amygdala. J Comp Neurol 269:381-391.

Moore RY (1978) Catecholamine innervation of the basal forebrain. I. The septal area. J Comp Neurol 177:665-684.

Morari M, Marti M, Sbrenna S, Fuxe K, Bianchi C, Beani L (1998) Reciprocal dopamine-glutamate modulation of release in the basal ganglia. Neurochem Int 33:383-397.

Nicholson C, Rice ME (1986) The migration of substances in the microenvironment. Ann NY Acad Sci 481:55-71.

Paxinos G, Watson C (1987) The rat brain stereotaxic coordinates. New York: Academic.

Pfaus JG, Damsa G, Wenkstern D, Fibiger HC (1995) Sexual activity increases dopamine transmission in the nucleus accumbens and striatum of female rats. Brain Res 693:21-30.

Phelix CF, Liposits Z, Paull WK (1992) Monoamine innervation of bed nucleus of stria terminalis: An electron microscopic investigation. Brain Res Bull 28:949-965.

Phelix CF, Liposits Z, Paull WK (1994) Catecholamine-CRF synaptic interaction in a septal bed nucleus: afferent of neurons in the bed nucleus of the stria terminalis. Brain Res Bulletin 33:109-119.

Pidoplicko VI, De Biasi M, Williams JT, Dani JA (1997) Nicotine activates and desensitizes midbrain dopamine neurons. Nature 390:401-404.

Pontieri FE, Tanda G, Orzi F, Di Chiara G (1996) Effects of nicotine on the nucleus accumbens and similarity to those of addictive drugs. Nature 382:255-257.

Rice ME, Gerhardt GA, Hierl PM, Nagy G, Adams RN (1985) Diffu- sion coefficients of neurotransmitters and their metabolites in brain extracellular fluid space. Neuroscience 15:891902.

Roberts DC (1993) Self administration of GBR 12909 on a fixed ratio and progressive ratio schedule in rats. Psycopharmacology 111:202-206.

Shalling M, Djurfeldt M, Hokfelt T, Ehrlich M, Kurihara T, Grengard P (1990) Distribution and cellular localization of DARP-32 mRNA in rat brain. Brain Res Mol Brain Res 7:139-149.

Tanda G, Pontieri FE, Frau R, Di Chiara G (1997a) Contribution of blockade of the noradrenaline carrier to the increase of extracellular dopamine in the rat prefrontal cortex by amphetamine and cocaine. Eur J Neurosci 9:2077-2085.

Tanda G, Pontieri FE, Di Chiara G (1997b) Cannabinoid and heroin activation of mesolimbic dopamine transmission by a common mu1 opioid receptor mechanism. Science 276:2048-2050.

Tella SR, Ladenheim B, Andrews AM, Goldberg SR, Cadet JL (1996) Differential reinforcing effects of cocaine and GBR-12909: biochemical evidence for divergent neuroadaptive changes in the mesolimbic dopaminergic system. J Neurosci 16:7416-7427.

Tetel MJ, Getzinger MJ, Blaustein JD (1993) Fos expression in the rat brain following vaginal-cervical stimulation by mating and manual probing. J Neuroendocrinol 5:397-404.

Villemagne VL, Rothman RB, Yokoi F, Rice KC, Matecka D, Dannals RF, Wong DF (1999) Doses of GBR 12909 that suppress cocaine self-administration in non-human primates substantially occupy dopamine transporters as measured by [11C]WIN35,428 PET scans. Synapse 32:44-50.

Wonnacott S (1997) Presynaptic nicotinic ACh receptors. Trends Neurosci 20:92-98. 